\title{
The role of national problems in European air quality regulation: the process of amplification
}

\author{
Tobias Arnoldussen ${ }^{1}$ (iD
}

Accepted: 22 January 2019 / Published online: 22 February 2019

(c) The Author(s) 2019

\begin{abstract}
Recurring themes in the literature on European environmental policy-making is the leaderlaggard spectrum and regulatory competition. European environmental policy is driven towards expansion because certain states take up leadership roles and manage to have their preferred regulatory solution adopted by the relevant European policy-making institution. During the policy process, leaders face 'laggards', states that do not favour ambitious regulation and drag their feet. The leader-laggard spectrum is volatile. States play different roles depending on the issue of interest, and over time their roles shift as well. This article investigates the role of relatively small-scale national events on the position of states on the spectrum. The regulatory competition involved in the leader-laggard spectrum may create an amplification effect of national problems: Through the efforts of the state afflicted by it, they acquire a European dimension they might otherwise not have had. They can cause member states to exhibit an extraordinary interest in a certain policy field and certain type of regulation for a brief period of time, shaping it considerably. After that, specific national problem has been solved or has blown over though they withdraw, leaving a gap for new contenders to fill. Yesterday's champions may be the laggards of tomorrow and vice versa. New champions bring their specific regulatory styles, their favourite solutions and their policy-making philosophy to bear on EU environmental regulation, exacerbating the already patchy character of this policy field.
\end{abstract}

Keywords Environmental policy · Air quality · Leader-laggard spectrum · EU policymaking $\cdot$ Environmental problems

The author would like to thank the anonymous reviewers of the manuscript for their thorough criticism on the earlier draft and thought-provoking remarks. In addition, I am grateful to readers and commentators who helped improve the manuscript, Marija Bartl, Alison Fischer, Nick Huls, Rob Schwitters, Olaf Tans, Jitte Waagen, Elly Leijenaar and my colleagues at the Paul Scholten Center for Jurisprudence.

Tobias Arnoldussen

n.t.arnoldussen@uva.nl

1 Faculty of Law, PPLE College, University of Amsterdam, Roetersstraat 11, Room: 4.06, 1018 WB Amsterdam, Netherlands 


\section{Introduction}

Over the years, the European Union has obtained a central place in the environmental governance of its member states (Selin and VanDeveer 2015; Jordan and Liefferink 2004). The EU's regulatory influence has been impossible to ignore, and a lot of research has been devoted to the question of what factors drive EU policy-making forward. The 'leader-laggard spectrum' and 'regulatory competition' are consistently recurring themes in this field (Héritier 1996; Héritier et al. 1996; Andersen and Liefferink 1997; Börzel 2002; Lenschow et al. 2014). The leader-laggard spectrum is a classification of countries according to the state of their environmental regulation. Countries with advanced regulation are expected to push for more ambitious policies, while those that have less advanced regulation are expected to stall policy development. Regulatory competition in the field of EU environmental policy denotes the phenomenon that countries compete with one another to have their domestic legislation 'uploaded' (Börzel 2002) to the level of the European Union policy (Héritier 1996; Héritier et al. 1996). To that end, they act as 'first movers', (Héritier 1996) by approaching the European Commission to argue why a certain issue is in need of regulation and offering a regulatory solution.

Authors point to a number of economic and institutional explanations to answer the question why countries act as leaders. From an economic point of view, it makes sense to be a first mover. If a highly regulated member state gets the European legislator to adopt its domestic form of regulation, it does not need to make adaption costs later on (Héritier 1996). Moreover, countries desire a European level playing field in order not to overburden their own industries. If a member state enacts ambitious regulation in a certain field, it is beneficial if other member states follow suit (Hanf and Van de Gronden 1998; Wurzel 2012). Additionally, institutional characteristics such as the level of affluence, a large green constituency (Börzel 2002), a well-developed knowledge infrastructure, consensual democracy and corporatism facilitate leadership roles (Haverland and Liefferink 2012). Jänicke (2005) explains environmental leadership by pointing to institutional factors as well, such as a high domestic capacity for environmental policy-making, a strong green advocacy coalition within a country and consensus around the theme of ecological modernisation.

Recent research indicates that the leader-laggard spectrum does not remain constant over time, but displays volatility. Countries do not occupy consistent positions (Liefferink and Birkel 2010; Wurzel 2012). Some countries such as the UK operate in some areas as laggards, for instance in emission standards, while in other areas they operate as leader states, for instance in the adoption of integrated pollution control (Héritier et al. 1996). Germany operates as a leader state on climate issues, but as a laggard on the subject of green mobility (Hey 2010).

This article considers the question why countries act as leaders or laggards as well. It argues that what role a country adopts is not only dependent on macro-institutional or economic factors, but also on relatively small-scale domestic political problems due to specific environmental events. With this article, I intend to draw attention to domestic events because they offer an additional explanation for why certain countries become highly regulated on specific issues. In addition to the institutional considerations mentioned above, countries also enact regulation in response to certain events and try to interest other states in adopting similar legislation.

A number of well-documented events had important consequences for policy-making. The dying of German forests, 'Waldsterben' in German, had a long-lasting impact on environmental policy, not only in Germany but also in the Netherlands (Böhmer-Christiansen 
and Skea 1991; Hajer 1995). Another well-known example is how the discovery of acidification of the Swedish lakes led to the first large-scale transboundary air pollution treaty in the 1970s (Wettestad 1999; VanDeveer 2004; Lidskog and Sundqvist 2002). Similarly, the great London smog of 1952 resulted in the enactment of the UK's Clean Air Act (Brimblecombe 2005; Thorsheim 2004).

The impact of events has not yet been systematically researched in the context of policy-making within the European Union. It is of interest though, because of the great mutual influence EU environmental policy and member states' policies have on each other. Through the Europeanisation process (Jordan and Liefferink 2004) of national environmental law and policy, local problems of one member state may lead to changes in the regulatory frameworks of others. If member states with certain specific national environmental problems manage to convince the Commission that European regulation is in order, and if the Commission's proposal indeed leads to legislation, then it is foreseeable that member states end up having to accept regulation tailored to a problem that they do not perceive as equally weighty.

To investigate the possible impact of national environmental issues on European regulation, I consider the history of the European air quality policy between 1990 and 2010. This case is an apt starting point because in this case we find a situation in which a traditional leader acted as a laggard and a laggard as a leader. This reversal of roles is not easily explained by changing economic or institutional factors, but can be understood when national, transient environmental events in the UK and the Netherlands are taken into account.

\subsection{Theoretical framework and methodology}

This article falls within the intergovernmentalist and constructivist approaches to European integration research as distinguished by Selin and VanDeveer (2015). It is intergovernmentalist because the main actors under consideration in this article are member states and the European Commission. It is also constructivist because it assumes that the member states' interests are defined by a social process of problem construction. The theoretical backbone of this article is formed by the constructivist theory of social problems laid down by Joel Best (2008).

Best proposes that social problems are the result of a process of claims-making by organisations of scientific experts, concerned citizens or other corporate actors. Claims makers consider a certain situation or event problematic and will try to bring their problem definition and their preferred solution to the attention of others. They try to attract media attention to make sure their claims are widely disseminated and influence the political process. If they have sufficient access and clout, they may also try to influence politicians directly to induce them to enact legislation. Claims makers are often opposed by other groups that benefit from the status quo. Best calls these actors counterclaims makers. The process of problem construction is inherently competitive. If claims attract enough supporters to become politically interesting, regulators may enact legislation in order to solve the problem. A novel feature of Best's approach is the observation that this legislation itself may become a target for new claims makers. Certain actors may perceive the new regulation as problematic and bring forth the claim that it needs to be changed, possibly leading to another cycle of the process of claims-making, finding supporters for the claim and eventual regulatory involvement. 
Best's model is crafted with national-level problems in mind. However, with adjustments, it may be applied to the supranational arena of the EU and combined with the notion of regulatory competition. This requires the following reformulation of Best's model: after claims makers have been successful in convincing regulatory bodies that there is a problem, the national government will enact regulation. When this member state has developed national legislation, it will try to 'upload' (Börzel 2002) its preferred regulatory solution to the European policy arena, in accordance with the theory of regulatory competition. In the words of Best, the member state will act as a claims maker, trying to induce the EU to adopt its favourite policy solution. Member states who oppose this solution will act as counterclaims makers and will drag their feet, or otherwise oppose the efforts of the claims maker. Member states who encounter problems with the regulation after its adoption will try to alter it, leading to a new cycle of claims-making at the EU level.

This adaptation of Best's theory allows me to stipulate a hypothesis that will be tested against the empirical data described below. The hypothesis is that national problems in member states may create a ripple effect that exceeds their national borders. Regulation in response to a national problem may be uploaded to Europe, and if it wins out in the European arena, member states face European regulation designed to tackle the specific problem of the claims-making state. This process amplifies environmental policy problems because they acquire a European dimension, whereas otherwise they might well have remained confined to the national arena. My term in this paper for the effect described above is the amplification effect of environmental issues.

When the claims-making member state is (at least partially) successful in uploading its preferred policy solution, member states will either be forced to adapt their national regulation to the new EU one, or try to successfully alter it. If the costs of implementation are perceived to be too high, they will argue for an amendment of the policy, especially if they do not consider the environmental issue in question to be very serious. They will stress that the entire regulation or features of it lead to problems and need change, offering their own regulatory approach as a solution. The result is an increase in the patchy character of environmental regulation, because it will incorporate elements from the regulatory traditions of various member states to an increasing degree.

The patchy character of EU environmental regulation is described numerous times in the literature (Héritier 1996; Knill and Liefferink 2007). My intention is not to refute the reasons given in the literature for the resulting patchwork, such as the compromises that will have to be struck within negotiations (Héritier 1996), or the different types of strategies used by leader states (Liefferink and Andersen 1998). The amplification effect would exacerbate the process by which elements from various regulatory traditions are continuously introduced into existing European frameworks because it elicits subsequent cycles of claims-making.

The article examines to what extent national events led to a process of amplification in the context of the EU air quality policy in the 1990s and 2000s. Two events are considered, the outbreak of concern over childhood asthma in the UK in the early 1990s and the blockade of road expansions by the Dutch courts due to air quality concerns around 2005.

These events have been chosen based on empirical findings in the context of my $\mathrm{PhD}$ research, for which the Dutch court cases formed a starting point. During my research into the European origin of air quality legislation, the importance of the asthma incident in the UK became evident. Air quality concerns drew scientific and media attention in other countries, for instance in Germany in the context of the Janacek case before the European Court of Justice (Der Spiegel 2007), but it did not lead to a legal clash as it did in the Netherlands (Arnoldussen 2016). Even though Northern Italy suffered from equally high levels 
of particulate pollution as the Netherlands, the health impacts did not become a subject of public debate during the time under scrutiny in this paper. ${ }^{1}$ In Belgium, no single court case was recorded in which air quality featured before 2006, even though access to justice and air quality are comparable to the Netherlands (Backes 2006).

For this article, I rely on data that have been compiled in the course of my study on the social problem of air quality in the Netherlands (Arnoldussen 2016). The discussion of the British and Dutch events is based on a comprehensive review of national policy documents obtained from the national archives. ${ }^{2}$ In addition to policy documents, I use material obtained from interviews with experts and policy makers and articles from well informed news outlets such as ENDS and the Euractiv website. For understanding the policy process leading to the current European Air Quality Directive, an online inventory of documents on expert meetings has been crucial (CAFE website).

The next section presents an overview of the emergence of the EU Framework Directive 96/62/EC on ambient air quality assessment and management (Framework Directive) and Air Quality Directive 99/30/EC (Daughter Directive). It answers the question why the UK championed both Directives by pointing to a health problem in the UK surrounding the apparent increase in asthma in children living close to highways.

Section three analyses the negotiations leading up to the Air Quality Directive 2008/50/ EC, henceforth the CAFE Directive. This Directive updated the air quality policies from the 1990s but also relaxed them significantly. This relaxation is related to Dutch pressure for postponement of the deadlines to comply with the clean air standards. The Dutch opposition will be traced back to national problems with the air quality standards blocking infrastructure development. The final section discusses the implications of the findings for the leader-laggard spectrum and answers the question is answered to what extent an amplification effect can be discerned.

\section{The construction of an EU air quality regime in the 1990s and the role of the UK}

The EU regulation on air quality as we know it today was shaped in the 1990s. It updated the Directives promulgated in the 1980s. In 1994, the Commission proposed a Framework Directive on Air Quality. The Framework Directive would not stipulate any concrete standards for air quality. It mainly sought to provide a harmonisation of measuring methods and strategic objectives and clear the ground for a number of Daughter Directives, which would contain standards. The work on the EU Framework Directive was undertaken at the same time as the UK started work on its own air quality strategy. The UK strategy was very comprehensive and contained limit values as well as strategic objectives, such as air quality control and management on a local level and provision of information to the public (Potter

\footnotetext{
1 The evidence I have for this is solely anecdotal. I asked an Italian chemist in 2008 if particulate pollution is an issue among Italians, and he told me there is an Italian word for it, but that it is of little concern to the population in general.

2 Dutch documents that contain written pieces such as letters to Parliament or minutes of previous meetings, start with the abbreviation TK (Tweede Kamer, Second Chamber of Parliament, comparable to the House of Commons), then the file number and the number of the debate in question in that certain file. Verbatim account of Debates start with 'Handelingen' (acts), then their number and date. UK documents start with House of Commons (HC), than the date of the debate, the number of the Hansard volume and the number of the Column in which the debate is laid down.
} 
1997). Elsom (1999) notes that the strategic outlook of the EU Framework Directive and the UK strategy was very similar because UK representatives were influential in the working groups negotiating the details of the EU's own approach.

Having representatives from member states on board was not uncommon at the time, because the understaffed Commission frequently accepted help from scientists and experts from member states with specific expertise during the Commission phase (Haverland and Liefferink 2012; Selin and VanDeveer 2015; Héritier 1996). Member states having the necessary knowledge infrastructure and sought after level of expertise used these resources to upload their preferred type of regulation to the EU level (Haverland 2009). A UK civil servant was dispatched to Brussels who was initially part of a team of experts that drafted a domestic air quality strategy in 1995 (interview UK senior civil servant, 14.07.2011, ${ }^{3}$ Channel 4 1999). According to Dutch experts involved in the preparations for the proposal of the Daughter Directive, she became a key expert helping the Commission during the preparation and negotiation of the Directives and who "constantly knew how to arrive at the right destination' (interview Dutch experts, 09.06.2009).

This senior official brought to the table what Haverland and Liefferink (2012 referred to as 'experiential knowledge'). The broad strategic outlook of Directive 96/62 resembles the UK strategy. Like the UK strategy, it focussed on local air quality control, on providing detailed information to the public and on the obligation for local governments to draft programs in case the standards are not met. According to the senior civil servant responsible for drafting the strategy, the UK strategy itself was not influenced by any other European model (interview UK senior civil servant, 14.07.2011). Local air quality control was not the preferred method of either the Dutch or the Germans. The Dutch linked quality standards to concrete administrative decisions concerning spatial planning (Drupsteen and Koeman 1996; Michiels 1998), and the Germans relied mainly on prescribing state-of-the-art technology (Wurzel 2002).

After the proposal of the more controversial Daughter Directive in 1997, the negotiation phase began with debates in the Council of Ministers and the European Parliament. Extraordinarily, a team of journalists was allowed to film the Council negotiations for a documentary film about EU politics (Channel 4 1999). The documentary makes clear that during these negotiations the UK civil servant played a pivotal role too. She had to defend the moderate position of the Commission against member states that did not like mandatory targets, such as Spain and France and against Sweden and Austria, who sought to set even more ambitious targets. Together with Germany and Belgium, the Netherlands supported the Directive as well, in order not to endanger its eco-friendly reputation, according to Rood et al. (2005).

Next to the Council, the European Parliament (EP) played an important role. UK influence was also present here. EP decisions are prepared in a special Committee dealing with environmental issues. This Environmental Committee prepares a report that is usually followed by the rest of the European Parliament (Bomberg and Burns 1999). Rapporteur for the proposal for the Daughter Directive was Labour MEP Anita Pollack from London. During the debates in the European Parliament, she explicitly mentioned the link between exhaust fumes and asthma, an issue very much in the public eye in the UK (EP 1998). Her report praised the proposal of the Commission as ambitious and urged for its quick adoption (ENVI 1998). The amendments brought forward by the committee mostly urged

\footnotetext{
${ }^{3}$ The names of the interviewees are on file with the author.
} 
for strengthening the public information requirements, and her report was adopted without many reservations (EP 1998).

Common position was eventually achieved between the Council and the EP in 1998, under the UK presidency. The limit values were strict, but southern countries received a number of exceptions based on the high amount of naturally occurring particle pollution. The limit values deviated somewhat from the British strategy, most notably with respect to nitrogen dioxide, for which the Directive set a stricter limit. The daily mean standards for particulate pollution, one of the most controversial and important values, did correspond with the UK target. The difference in the limit values was due to their different origins, the EU limit values were based on WHO guidelines (Wettestad 2006), while the UK standards were based on scientific studies by its public health body EPAQS.

In many ways, the strategic aspect of local pollution control corresponded to the UK strategy, but there were differences: under the UK strategy it was permissible to exceed limit values when important other interests are at stake. This was not possible under the EU Directive. The drafter of the original UK strategy considered both the high NO2 standard and the rigidity of the limit values examples of bad policy-making (interview UK senior civil servant 14.07.2011).

Apparently even champions do not get exactly the Directive they desire. The question remains why the UK played such an active role and why it drafted its own regulation in the first place. A more in-depth review of the British situation in relation to air quality in the mid-1990s sheds light on this question.

\subsection{The UK asthma incident}

The question why the UK championed the air quality Directive is partially explained by pointing out that the UK drafted policy in answer to domestic problems of its own, namely concerns over asthma. The Conservative government felt under pressure over air pollution; protests against road expansions and after 13 years in power conceivably it exhausted its own agenda (interview UK senior civil servant, 14.07.2011).

The attention for asthma started with a smog episode in 1991 during Christmas. In answer to parliamentary questions in January the following year, the Conservative government assigned a scientific Committee, the Quality of Urban Air Review Group (QUARG) with the task to examine urban air quality. One of the MPs that warned about the threat of asthma was Jeremy Corbyn. In February 1992, he asked for the figures of the relationship between asthma and pollution from motor vehicles. He lambasted the government for failing to produce these figures and stated that fewer cars should be driving through London in order to '... preserve the health of our children who are suffering grievously' (HC 1992a). The Government was at the time busy realising a comprehensive program of road expansion and the issue of asthma got increasingly tangled up with the highly visible road protest in the UK in the 1990s (Wall 2002, p. 81). In the summer of 1992, labour MP's began questioning about air quality near the major M1 road near Sheffield. These questions were followed by similar questions about NO2 in London (HC 1992b, c).

In 1993 and 1994, the campaign against roads and the concerns with air quality became increasingly fuelled by newspaper attention for childhood asthma, especially after summer smog episodes (The Guardian 30.05.1993, 01.06.1993). The issue of coughing children started to interest even the Financial Times (30.06.1993).

The asthma scare reached its zenith in the summer 1994. On the first weekend of July 1994, the government warned of bad air pollution from ozone. Newspapers discussed the 
bad air quality situation in jittery terms. The Guardian expected that high ozone levels may be here to stay and implied that London might go the route of Athens or Mexico City (The Guardian 05.07.1994). On July 16th, the Independent reported about an asthma incident following the evening of June 24th. On its front page, it stated that after a period of severe thunderstorms that night the hospitals became overcrowded with people suffering from asthma. The doctors compared the situation to 'a plane crash happening near every hospital'. The headline read: 'the day Britain choked' (The Independent 16.07.1994). The Guardian asked 2 days later for: 'A politician that can clear the air', because: 'we were told that legislation had banished smog, but now it is stiflingly, chokingly, sometimes murderously, back' (The Guardian 18.07.1994).

The Labour opposition upped the pressure and unveiled its own proposal to handle air pollution and smog a few days earlier. It presented a document in which it portrayed air quality as a very serious issue. Spokesperson for the environment Chris Smith linked it to the 'asthma epidemic [...] across the country' (The Guardian 13.07.1994).

The conservative government was initially slow to respond, but started to make haste when the issue picked up steam. The government issued a discussion paper in March 1994 and a draft strategy: 'Air Quality Meeting the Challenge' in January 1995 (Potter 1997). When the government amended the Environmental Protection Act in June 1995 to include the strategy, the Conservatives tried to claim they were the party to vote for if something needed to be done for air quality (HC 1995). Labour won the 1996 elections though, mostly on matters unrelated to air quality. The new cabinet did promise it would be the greenest government Britain had had, but in later years it did not prioritise the environment as much as initially declared (Carter 2001).

After the UK adopted a progressive air quality strategy, it made sense to export this strategy to Europe and make sure a level playing field of environmental regulation was maintained. It wanted a regulation that resembled its own. The concern over asthma together with concerns over the increase in traffic and the need for the Conservatives to come up with a new policy agenda, provided the impetus for this strategy.

In this case, a country traditionally regarded as a laggard assumed the role of leader, due to domestic considerations. The converse process is also possible. Domestic trouble can cause a traditional leader state to adopt the role of laggard. This situation is illustrated by the adoption of the so-called CAFE Directive and the Dutch domestic legal battle over the air quality legislation.

\section{The Dutch applying the brakes: the CAFE Directive 2008/50/EU}

Quickly after the adoption of the Daughter Directive, the Commission decided on an overhaul of the policy in $2001 .{ }^{4}$ This new strategy integrated different policies, such as acidification policy, policies on emissions and air quality. This operation required a large-scale program which was set up under the acronym 'CAFE' (Clean Air For Europe). In various working groups, experts and policy makers would get together to design a coherent strategy (European Commission 2001). CAFE was a daunting process

\footnotetext{
4 The question why this happened falls outside the scope of this article, but the accession of the Nordic member states in 1995, probably played a part. The sixth Environmental Action Plan which included CAFE as one of the thematic strategies seems to be influenced by a Swedish style of policy-making (Kronsell 1997).
} 
involving more than one hundred stakeholder meetings in a time span of 5 years (European Commission 2005a). It included a proposal for a Directive (European Commission 2005 b), but also a general overarching strategy to reduce air pollution emitted by various activities such as transport and energy.

Already during the negotiation of the Daughter Directive, the Dutch government realised that the standards laid down for particulate matter and nitrogen dioxide would not be easy to meet (Rood et al. 2005). Minister Pronk sent a letter to Environmental Commissioner Margot Wallström, trying to persuade her that the Netherlands needed some clemency from the Commission. However, Brussels made no concrete promises (Interview former Dutch environment Minister, 03.12.2012).

The Netherlands lobbied to obtain extra time for member states to comply with the directive. Dutch experts put forward the position of the Netherlands in various working groups. The Netherlands acquired the chair of the working group on implementation in 2002, and this working group advised to allow member states extra time, in line with the wishes of the Dutch Government (WG IMP 2004). The civil servant chairing the Working Group on Implementation also tried to call attention to the Dutch position in the important CAFE Steering Group (2004).

In 2004, the Dutch judiciary began blocking infrastructure projects because of noncompliance with the air quality standards. After these high profile court cases, the Netherlands stepped up its efforts considerably. During the Commission phase, the Netherlands actively sought allies for its position and indicated that it would not accept any new standards until implementation issues with the policy had been resolved (CAFE Steering Group 2005).

During the negotiation phase, the Dutch secretary of state for the environment, the Christian democrat Pieter Van Geel tried to convince other member states of the necessity of extra time to comply. The European lobby undertaken by the Netherlands is detailed in his letter to Parliament (TK 2006a). In the Council of Ministers, the Netherlands opposed the new air quality standards proposed by the European Commission in 2005. Together with other Ministers the secretary of state requested the possibility to postpone compliance (ENDS 2005). He tried to mobilise other member states and claimed that Poland, Hungary and the Baltic States were on his side (ENDS 2006; VROM 2006). Eventually, the Netherlands voted against the proposal in the Council of Ministers together with Poland, an unprecedented move.

In the European Parliament, the Netherlands was more successful in obtaining the alliances it desired. It is accepted wisdom that the European Parliament is usually more environmental friendly than the Council (Burns 2005), but this time it supported the call for postponements. In this process, Dutch experts and policy makers were influential, together with MEPs from Germany. Two reports were prepared in the EP's Environmental Committee, one for the overall CAFE strategy by a Dutch Socialist MEP and one for the proposed directive written by a German Liberal Conservative MEP (ENVI 2006a). The Committee's draft report on the Directive was already favourable for member states that were struggling. It offered an extension of the deadline of 5 years after the adoption of the Directive. However, Dutch MEPs together with an active German Christian democrat MEP, managed to include an amendment which made sure member states could postpone compliance for another 5 years (ENVI 2006a, am 30. ENVI 2006b, am 121 and 122). The Dutch MEPs had ammunition at their disposal in the form of an expert report (Jimmink et al. 2004), which argued that the baseline assumptions in the CAFE models were incorrect (Jimmink, e-mail correspondence, 31.05.2013). To the dismay of the more environmental friendly factions in the EP, the Environmental Committee's report was adopted (EP website). 
The position of Parliament brought it into conflict with the Council, but in the end a compromise was reached in informal negotiations. The CAFE Directive granted a lot of extra time to member states to meet the standards and disappointed European Commissioner Stavros Dimas (Website Euractiv a).

The Netherlands was not the Directive's only opponent. The opposition from business interests and other Directorates General within the Commission was crucial as well (Meuwese 2008). However, the Dutch lobby raised the issue of postponements quickly, first in the Commission phase and later in the negotiation phase. Especially in Parliament, it found a willing ear. It is hard to say how far reaching Dutch influence was. Opposition from Industry played a strong role too, either directly or through influencing other actors such as the Directorate General for Energy (Meuwese 2008). It is clear that the Netherlands had people in important positions, just like the UK had before. It acquired prominence in the Working Group on Implementation through which it made its wish for derogations known and it made a lot of noise in the Council meetings. Dutch MEPs were active in the Environmental Committee of the EP where they did find allies in German MEPs who were also concerned with issues of implementation. While its influence is hard to gauge compared to other actors, clearly the Dutch played the role of foot dragger in this case.

The question why the Netherlands applied the brakes on a file which it previously supported, may be answered again by looking at its domestic situation. The Netherlands suffered economic setbacks because of the air quality regulation, and this led to political struggles between the government and the judiciary.

\subsection{The air quality clash}

In this case, the reasons that the Netherlands took the position of unexpected laggard are similar to the reasons for the UK to be a remarkable forerunner: the emergence of local social problems. In 2001, a conservative government was installed in the Netherlands and it had the expansion of Dutch roads as a top priority. To that end, the Dutch government issued an emergency law on road expansion that should significantly speed up the process of road expansion, making their timely realisation more certain.

The acceptance of this law in Parliament was relatively straightforward, but in May 2004 the road expansions met with severe legal setbacks due to the air quality regulation. First, a road expansion was terminated by the Dutch Administrative Court in May 2004. In September that year, a second road expansion was halted by the Administrative Court and it became clear the Emergency Law had backfired. These terminations led to a hitherto unprecedented administrative deadlock over environmental standards. Newspapers and legal professionals warned that the Netherlands was 'barred' from further infrastructure development (Schutte-Postma et al. 2006). Many road expansions, but also high profile infrastructural and housing projects were all terminated or postponed because of exceedance of the air quality standards (Arnoldussen 2016).

Initially, this situation led to critical questions regarding the quality of the air in the Netherlands. Especially left wing parties in opposition to the Government demanded an increase in the budget to improve air quality (Acts 2005). Quickly measures were taken such as speed reduction on tracts of motorway. In the 2006 budget, the government included nine hundred million euros to improve the air quality in the Netherlands (TK 2005). However, the government also sought to amend the Dutch implementation of the Air Quality Directives. Early 2005, the responsible secretary of state introduced a proposal in Dutch law to quickly fix the problems caused by the Directives. In the Netherlands, 
policy proposals have to pass the Council of State for advice. This is a powerful institution in Dutch policy-making, consisting of two sections. It is mandatory to consult the advisory section when legislation is concerned and the second section acts as the highest administrative court, reviewing decisions of the central government and lower administrative bodies (De Moor-van Vugt 2014). The advisory section of the Council of State considered that the Netherlands did not have the possibility to amend European law by national measures, due to the primacy of European law. Time and again, The secretary of state's proposals were met with criticism from this advisory body (Council of State 2005a, b).

Gradually, the tone of the debates shifted to discontent with the European regulation of air quality. The position of the Netherlands in Europe was discussed in Parliament in 2005 and 2006 in an atmosphere of animosity towards Brussels, the courts, and the Council of State. Brussels was blamed for halting further development of the Netherlands, because it promulgated badly researched standards (Acts 2006a). Other MP's were even more vehement in criticising the European Union for 'meddling' in Dutch regulatory affairs, when politicians questioned whether in fact the Council of State together with European Union ruled instead of Parliament (Acts 2006b; TK 2006b).

During a debate on 22 June 2006, (TK 2006c) just before the vote in the Council of Ministers, parliamentarians demanded that the Netherlands would not make the same mistake again of supporting an unattainable Air Quality Directive. The secretary of state promised that if the Netherlands would not obtain a good deal, he would vote against the Directive in the European Council of Ministers, which indeed he did (Waterhout 2007).

When the Directive was finally accepted by both Council and Parliament in 2007, the Netherlands did not try to stop it. It even urged for its quick adoption (TK 2007)! The reason for this change was that in 2006 and 2007 a new legal instrument had been devised, the so-called programmatic approach. This programmatic approach allowed for a plan based on balancing measures to clean the air with projects that would lead to extra pollution (Boeve and Van den Broek 2012). With this plan, the Netherlands indicated it would meet the standards after a number of years. As mentioned above, the CAFE Directive included the possibility to ask for postponements by countries who could show that they made efforts to meet the standards. This clause granted the Dutch the necessary time to implement the programmatic approach, hence its now enthusiastic reception.

The air quality clash in the Netherlands was solved by a combination of the revision of the air quality regulation and the programmatic approach. Such a program based approach was mentioned in the UK air quality strategy and the earlier Air Quality directives, but alien to Dutch spatial planning. Now, it has gained a prominent place in the proposal for a new Environment and Planning Act (Boeve and Groothuijse 2014). Eventually, the Netherlands 'downloaded' a European policy instrument and has now fitted it into its own regulatory tradition.

\section{The implications of local events}

The incidents under consideration in this article, the UK asthma incident and the Dutch air quality clash have now by and large blown over. The Dutch air quality clash has almost been forgotten. Even though air quality is still used by NGO's to challenge road construction in the administrative courts, the chances of it leading to annulment have become very slim since 2010 (Van der Sluis 2011). 
In the UK, urban air quality is still an issue; however, the relation between childhood asthma and car exhausts is unclear and concern faded. According to a 2010 statement by the authoritative UK body Committee On the Medical Effects of Air Pollution (COMEAP) (2010), it is unlikely that outdoor air pollution played any significant part in the causation of asthma among the general population.

Héritier (1996) argues that highly regulated member states have an interest in exporting their own favourite policies to the European arena. She does not address the question why states become highly regulated in the first place. To answer that question, Jänicke (2005) points to institutional factors such as green advocacy coalitions and the embrace of an ecological modernistic policy philosophy. Haverland and Liefferink (2012) emphasise the presence of a well-developed knowledge infrastructure in a member state. The role of local events and political problems has received less attention, but it adds to the current set of explanations for why states become highly regulated.

The UK became a highly regulated forerunner state in the field of air quality, partly because the population started to worry about the possibility that exhaust fumes caused asthma in children. The large amount of scientific committees on air quality started work because of fears among the population. Political campaigners could subsequently link the issue to already existing protests against road expansion. The emergence of the asthma scare fuelled the development of a large knowledge infrastructure and strengthened the development of green interest coalitions. This local problem caused a sense of urgency in government circles, and hereafter the air quality strategy became an important political topic. After having adopted this strategy, the UK made efforts to export it to the European Union and it succeeded because the Commission already planned to overhaul existing legislation. The emphasis in this article on the role of local events does not contradict the reasons mentioned by the other authors cited above; in fact, they are intimately related. Events do not occur in a vacuum, but within institutional contexts. Similarly, however, the development of institutional capacity often occurs in response to concrete events that cause experts, pressure groups and other social actors to make regulatory demands. Institutional factors and factors related to local events reinforce each other.

The situation in the Netherlands was opposite to the UK. In the Netherlands, the air quality regulation itself led to problems. Faced with political problems at home, the Netherlands tried to gain influence first in expert groups and later in formal legislative institutions like the Council and the European Parliament. It openly showed opposition to progressive European policy, contrary to the tradition of the Netherlands as a constructive but cautious leader (Liefferink and Andersen 1998).

The Dutch clash over the air quality regulation is embedded in institutional settings as well. The clash occurred because of numerous cases being brought before the administrative court, owing to the relatively open access of citizens and pressure groups to these courts. Moreover, Dutch legal doctrine linked air quality standards directly to local administrative decisions, which explained the success of the cases brought against Dutch administrative bodies over air quality. The crisis exacerbated the tendency to play a more defensive role on environmental issues that was already taking shape (Liefferink and Birkel 2010), but it also led to an overhaul of the Dutch system of spatial planning, making it more consistent with current European policy philosophy. Also in the case of the Netherlands, events and institutional change influenced each other and this had direct effects on its position in European negotiations.

The findings in this case study are consistent with those of David Vogel (2003). Vogel describes how the EU became on many terrains a more highly regulated environmental block of countries than the USA. He shows how events such as the emergence of the BSE 
health crisis and the scare of dioxin in baby milk impacted the EU policy on food safety and let to tighter regulatory controls. At the same time, these tighter controls lead to more public scrutiny and a more risk-averse constituency. Pointing to the role of local events is a useful addition to the existing institutional explanations for leader and laggard behaviour, especially in showing why certain institutional arrangements emerged. Events and institutions should not be viewed in isolation, but viewed as related to each other.

\subsection{The amplification effect}

When the theoretical framework outlined in Sect. 1.1 is applied to the events in the UK and the Netherlands, it becomes clear that local events in these countries did indeed have effects that transcended national boundaries, due to the peculiar nature of the European policy arena. An amplification effect is visible. A national event, the asthma scare, brought a certain environmental problem to the fore and legislators responded accordingly. When national legislation was in place, it made sense to 'export' this type of legislation to the European arena, in accordance with the findings in the leader-laggard literature. When this legislation was indeed adopted community wide, the original claims-making member state lost interest in it. Member states who had to incur large costs to comply with the Directive on the other hand had an incentive to fill the gap left behind, and they tried to alter it. In the Netherlands, the problem was reframed from a problem of bad air quality to a problem of bad regulation of air quality. It fed back this problem definition into the European policy arena, and when it became shared by MEPs from other nationalities, this view started to dominate discussions in the European Parliament. The asthma problem had an amplification effect, because it affected Dutch environmental policy indirectly through European policy-making. The Dutch legal clash over air quality regulation also had an amplification effect, because partly through Dutch involvement the CAFE Directive was watered down, against the wishes of member states who did not experience any problem with it.

However, the amplification effect became significantly diluted and modified in all the stages of the policy-making cycle. A diverse group of actors influenced the policy proposals, such as the European Commission, the European Parliament and other member states. The limit value for NO2 and the strictly binding character of the limit values laid down in Directive 99/30 for instance were both not intended by the UK. The strictness of both the values and the binding character caused problems in the Netherlands. Hence, the exact way national events get amplified is unpredictable and might be caused by amendments made later in the process, even by other actors than the original champion.

The amplification effect of local events in EU environmental policy-making adds to the existing explanations for the patchy character of European environmental policy, but does not replace them. Héritier (1996) states that the patchwork of regulation is the result of actors needing to compromise and to coordinate interests. This often leads to policy mixes, in which instruments of different regulatory traditions are cobbled together. Indeed, the air quality policy contained a lot of compromises and coordination of interests. The Netherlands managed to get its points across in some of the EU institutions, but not in others. The final result was a compromise between the more ambitious position of the Council and the more 'laggard friendly' position of the EP.

Nonetheless, the dynamic of amplification is still visible. Nationally important problems, such as a scare over childhood asthma in the UK or air quality regulation for the Netherlands, are put on the European agenda, causing them to become European issues. They gain an amount of importance that might not be justified considering their national 
scope and short lived nature. This dynamic causes an increase in the patchwork of regulatory instruments, but also in problem awareness, because every claims-making member state has to convince other member states that the problem is serious and merits European consideration. This dynamic may be applied to David Vogel's observation that the European public becomes increasingly risk averse (Vogel 2003). As it becomes more aware of potential hazards through their European regulation, it also becomes increasingly worried, creating additional demand for regulation, explaining the European turn towards a precautionary approach (Vogel 2003; Pieterman 2008).

This case study showed that the European policy-making arena is unpredictable, that makes it hard to generalise the findings of this study. It remains very hard to predict which local problems might be amplified and which may not. Further research into case studies from different fields is needed to investigate whether local events played an important role and, if so, whether they were amplified to the level of salient European wide political concerns.

\section{Conclusion}

European environmental policy is shaped by a leader-laggard dynamic, but which member state will play the part of leader and which that of the laggard is often unpredictable. In addition to the more or less predictable macro-institutional, economic and policy-philosophical considerations, the air quality case shows that micro-level events in member states play a role. Member states may act as leaders or laggards because of nationally felt political problems over environmental conditions or, on the contrary, their European regulation.

This dynamic creates an amplification effect of national problems: they can cause member states to exhibit an extraordinary interest in a certain policy field and certain type of regulation for a brief period of time, shaping it considerably. After that, national problem has been solved or has blown over though they withdraw, leaving a gap for new contenders to fill. Yesterday's champions may be the laggards of tomorrow and vice versa. New champions bring their specific regulatory styles, their favourite solutions and their policy-making philosophy to bear on EU environmental regulation. A champion will take regulation in a certain direction in order to solve the particular problems it has. However, once it has 'won', another will take over and propose its own favourite type of solution. The air quality policy bears the marks of British and Dutch but also German and Swedish styles of regulation. All these different approaches containing their own specific terminology and rationale are piled upon each other shaping EU policy, though not necessarily in the way intended by the erstwhile champion.

Keeping national small-scale events in focus while studying European policy-making is useful because their long-term impact may be bigger than assumed at first glance and they may exhibit unpredictable amplification effects. In that vein, it is worthwhile to research whether the recent emission scandals involving Volkswagen and other key brands operating in the German car industry influenced Germany's stance in the European arena. Similarly, the recent 'fishing row' between France and the Netherlands may be fruitfully analysed using the concept of amplification. The mainly economic row over the use of electric pulse fishing techniques was redefined as an environmental one causing France to take the lead to ban pulse fishing (euractiv b website). It is interesting to see whether this row will induce France to take a leader role on the issue of the protection of marine life. When we aim to understand the development of European policy and law, it pays off to look at the 
European arena, while keeping close tabs on national developments. National problems may become amplified, leading to a dynamic in which different member states successively steer a certain policy field towards the destination it happens to favour, without much eye for a common way forward.

Open Access This article is distributed under the terms of the Creative Commons Attribution 4.0 International License (http://creativecommons.org/licenses/by/4.0/), which permits unrestricted use, distribution, and reproduction in any medium, provided you give appropriate credit to the original author(s) and the source, provide a link to the Creative Commons license, and indicate if changes were made.

\section{References}

Andersen, M. S., \& Liefferink, D. (Eds.). (1997). European environmental policy: The pioneers. Manchester: Manchester University Press.

Arnoldussen, N. T. (2016). The social construction of the Dutch Air Quality Clash, how road expansions bit the dust against particulate matter. The Hague: Eleven International Publishing.

Backes, C. (2006). Internationale vergelijking implementatie EU-richtlijnen luchtkwaliteit, Report IKC1923. Utrecht: CELP/NILOS.

Best, J. (2008). Social problems. New York: W.W.Norton \& Company.

Boeve, M., \& Groothuijse, F. A. G. (2014). Programmatische aanpak in de Omgevingswet: ruimte voor ontwikkeling, waarborgen voor kwaliteit? Tijdschrift voor Omgevingsrecht., 2014(3/4), 71-80.

Boeve, M. N., \& Van den Broek, G. M. (2012). The programmatic approach; A flexible and complex tool to achieve environmental quality standards. Utrecht Law Review, 8(3), 74-85.

Böhmer-Christiansen, S., \& Skea, J. (1991). Acid politics: Environmental and energy policies in Britain and Germany. London: Belhaven Press.

Bomberg, E., \& Burns, C. (1999). The environment committee of the European Parliament: New powers, old problems. Environmental Policy, 8(4), 174-179.

Börzel, T. A. (2002). Pace-setting, foot-dragging, and fence-sitting: Member state response to Europeanization. Journal of Common Market Studies., 40(2), 193-214.

Brimblecombe, P. (2005). The globalization of local air pollution. Globalizations, 2(3), 429-441.

Burns, C. (2005). The European Parliament, The European Union's environmental champion? In A. Jordan (Ed.), Environmental policy in the European Union: Actors institutions and processes. London: Earthscan.

Carter, N. (2001). The politics of the environment. Cambridge: Cambridge University Press.

COMEAP. (2010). COMEAP Statement. 02-12, 2010, COMEAP. http://www.ihsti.com/lacors/ContentDet ails.aspx ?id=24666. Last accessed January 1, 2019.

De Moor-van Vugt, A. J. C. (2014). Uitgespeeld? Over de rol van de Raad van State in de Nederlandse bestuursrechtspraak. In M. Van Damme (Ed.), De hervorming van de Raad van State (pp. 297-318). Brugge: Die Keure.

Drupsteen, Th G, \& Koeman, N. S. J. (Eds.). (1996). Tekst en Commentaar: Wet Milieubeheer. Deventer: Kluwer.

Elsom, D. M. (1999). Development and Implementation of strategic frameworks for air quality management in the UK and the European Community. Journal of Environmental Planning and Management, 42(1), 103-121.

Hajer, M. A. (1995). The politics of environmental discourse, ecological modernization and the policy process. Oxford: Clarendon Press.

Hanf, K., \& Van de Gronden, E. (1998). The Netherlands: Joint regulation and sustainable development. In K. Hanf \& H. I. Jansen (Eds.), Governance and environmental quality in Western Europe (pp. 152180). Essex: Addison Wesley Longman.

Haverland, M. (2009). How leader states influence EU policy-making: Analysing the expert strategy. European Integration online Papers (EIoP), (13), 2009. Available at SSRN: https://ssrn.com/abstr act $=1553787$.

Haverland, M., \& Liefferink, D. (2012). Member State interest articulation in the commission phase. Journal of European Public Policy, 19(2), 179-197.

Héritier, A. (1996). The accommodation of diversity in European policy-making and its outcomes: Regulatory policy as a patchwork. Journal of European Public Policy, 3(2), 149-167. 
Héritier, A., Knill, C., \& Mingers, S. (1996). Ringing the changes, regulatory competition and the transformation of the state. Berlin: Walther de Gruijter.

Hey, C. (2010). The German Paradox: Climate leader and green car laggard. In C. Oberthuer \& M. Pallemaerts (Eds.), The new climate policies of the european union internal legislation and climate diplomacy (pp. 211-230). Brussels: VUB Press.

Jänicke, M. (2005). Trend-setters in environmental policy: The character and role of pioneer countries. European Environment, 15(2), 129-142.

Jimmink, B. A., Folkert, R. J. M., Thomas, R., Beck, J. P., van Eerdt, M. M., Elzenga, H. E., et al. (2004). The Dutch CAFE baseline: In or out of line? A review on the current information in the RAINS model. Bilthoven: RIVM.

Jordan, A., \& Liefferink, D. (2004). The Europeanization of national environmental policy. In A. Jordan \& D. Liefferink (Eds.), Environmental policy in Europe. The Europeanization of national environmental policy (pp. 1-14). London: Routledge.

Knill, C., \& Liefferink, D. (2007). Environmental politics in the European Union. Policy-making, implementation and patterns of multi-level governance. Manchester: Manchester University Press.

Kronsell, A. (1997). Environmental policy in Sweden-Setting a good example. In D. Liefferink \& M. S. Andersen (Eds.), European environmental policy: The pioneers. Manchester: Manchester University Press.

Lenschow, A., Liefferink, D., \& Jörgens, H. (2014). Complex causation in cross-national policy convergence. In H. Jörgens, D. Liefferink, \& A. Leschow (Eds.), Understanding environmental policy convergence: The power of words, rules and money (pp. 265-295). Cambridge: Cambridge University Press.

Lidskog, R., \& Sundqvist, G. (2002). The role of science in environmental regimes: The case of LRTAP. European Journal of International Relations, 8(1), 77-101.

Liefferink, D., \& Andersen, M. S. (1998). Strategies of the 'green' member states in EU environmental policy-making. Journal of European Public Policy, 5(2), 254-270.

Liefferink, D., \& Birkel, K. M. (2010). The Netherlands: A case of 'cost-free' leadership. In R. Wurzel \& J. Connelly (Eds.), The European Union as a Leader in International Climate Change Politics (pp. 146-162). London: Routledge.

Michiels, F. C. M. A. (1998). De Wet Milieubeheer. Deventer: Tjeenk Willink.

Meuwese, A. (2008). Impact assessment in EU law making. The Hague: Kluwer Law International.

Pieterman, R. (2008). De voorzorgcultuur, streven naar veiligheid in een wereld vol risico en onzekerheid. Den Haag: Boom Juridische Uitgevers.

Potter, S. (1997). The national air quality strategy. Research paper 97/33. House of Commons Library, London. https://researchbriefings.parliament.uk/ResearchBriefing/Summary/RP97-33\#fullreport.

Rood, J., Van Keulen, M., Nollen, S., \& Arts, G. (2005). Nederland en de Totstandkoming van EU MilieuRichtlijnen, Eindrapport. Den Haag: Clingendael.

Schutte-Postma, E. T., Van der Feltz, G. C. W., de Hoop, M., Groen, R. H., \& Blom, W. (2006). Regeling inzake luchtkwaliteit; Nederland op slot?. Den Haag: Vereniging voor Milieurecht, Boom Juridische Uitgevers.

Selin, H., \& VanDeveer, S. (2015). EU environmental policy-making and implementation: Changing processes and mixed outcomes. Paper presented at the 14th Biennial conference of the European Union Studies Association, Boston, MA, March 2015.

Thorsheim, P. (2004). Interpreting the London Fog Disaster of 1952. In E. M. Dupuis (Ed.), Smoke and mirrors: The politics and culture of air pollution (pp. 154-169). New York: NYU Press.

VanDeveer, S. (2004). Ordering environments: Regions in European International Environmental Cooperation. In S. Jassanoff \& M. L. Martello (Eds.), Earthly politics, local and global in environmental governance (pp. 309-334). Cambridge, MA: The MIT Press.

Van der Sluis, C. N. (2011). Luchtkwaliteit in de jurisprudentie. Programmasystematiek blijft haar waarde bewijzen. Tijdschrift voor Omgevingsrecht, 2011(4), 109-115.

Vogel, D. (2003). The hare and the tortoise revisited: The New politics of consumer and environmental regulation in Europe. British Journal of Political Science, 33(04), 557-580.

VROM. (2006). Duurzaam VROM, Ambities, Daden en Dillemma's, maatschappelijk jaarverslag 2006. Den Haag: VROM.

Wall, D. (2002). Snowballs, Elves and Skimmingtons, genealogies of environmental direct action. In B. Doherty, M. Paterson, \& B. Seel (Eds.), Direct action in British environmentalism (pp. 79-92). London: Routledge.

Waterhout, B. (2007). Episodes of Europeanization of Dutch national spatial planning. Planning, Practice \& Research, 22(3), 309-327.

Wettestad, J. (1999). Designing effective environmental regimes: The key conditions. Cheltenham: Edward Elgar. 
Wettestad, J. (2006). The EU Air Quality Framework directive: Shaped and saved by interaction? In S. Obertuer \& T. Gehring (Eds.), Institutional interaction in global environmental governance: Synergy and conflict among international and EU policies (pp. 285-306). Cambridge, MA: MIT Press.

Wurzel, R. (2002). Environmental policy-making in Britain, Germany and the European Union: The Europeanisation of Air and Water Pollution Control. Manchester: Manchester University Press.

Wurzel, R. (2012). Member states and the Council. In A. Jordan \& C. Adelle (Eds.), Environmental policy in the EU, actors institutions and processes (3rd ed., pp. 75-94). London: Routledge.

\section{Policy and technical documents}

Acts. (2005). Handelingen II 2004-2005, nr. 34.

Acts. (2006a). Handelingen 2005-2006, nr. 22.

Acts. (2006b). Handelingen II 2006-2007 nr. 14.

CAFE Steering Group. (2004). 9th CAFE Steering Group Meeting-Minutes Brussels, May 17-18, 2004.

CAFE Steering Group. (2005). 13th CAFE Steering Group Meeting-Minutes Brussels, April 14, 2005.

Council of State. (2005a). Advice of the Council of State, W08.05.0081/V/A, Maart 30, 2005.

Council of State. (2005b). Advice of the Council of State, W08.05.0401/V, November 11, 2005.

ENVI. (1998). A4-0161/98. Report on the proposal for a Council Directive relating to limit values for sulphur dioxide, oxides of nitrogen, particulate matter and lead ambient air. (COM(97)0500-C4-0662/9797/0266(SYN)). April 27, 1998. Rapporteur Anita Pollack.

ENVI. (2006a). A6-0234/2006. Report on the proposal for a Directive of the European Parliament and of the Council on ambient air quality and cleaner air for Europe. (COM(2005)0447-C6 0356/20052005/0183(COD)). June 29, 2006. Rapporteur Holger Krahmer.

ENVI. (2006b). PE 371.908v01-00. Draft report on the proposal for a Directive of the European Parliament and of the Council on ambient air quality and cleaner air for Europe. (COM(2005)0447-C6 0356/20052005/0183(COD)), amendments 36-195. June 29, 2006. Rapporteur Holger Krahmer.

EP. (1998). Report of proceedings from 11 May to 15 May 1998, Official Journal of the European Communities annex, 4-519, May 12, 1998.

European Commission. (2001). SEC(2001) 688. Commission Staff Working Paper On Clean Air For Europe. Brussels, May 4, 2001.

European Commission. (2005a). COM(2005)446 final. Communication from the Commission to the Council and the European Parliament, Thematic Strategy on air pollution. Brussels, September 21, 2005.

European Commission. (2005b). COM(2005)447 final. Proposal for a DIRECTIVE OF THE EUROPEAN PARLIAMENT AND OF THE COUNCIL on ambient air quality and cleaner air for Europe. Brussels, September 21, 2005.

HC. (1992a). HC Deb 19 Feb 1992 vol 204 col. 323.

HC. (1992b). HC Deb 10 June 1992 vol 209 cc. 189-90.

HC. (1992c). HC Deb 11 June 1992 vol 209 cc. 265-66.

HC. (1995). HC Deb 28 June 1995 vol 262 cc. 997-98.

TK. (2005). TK 2005-2006, 30175 nr. 10.

TK. (2006a). TK 2005 - $200621501-08$ nr. 219.

TK. (2006b). TK 2006-2007, 30489 nr. 25.

TK. (2006c). TK 2005 2006, 22112 nr. 454

TK. (2007). TK 2007-2008, 30 175, nr. 259

WG IMP. (2004). Recommendations on the review of Council Directive 1999/30/EC, June 2004.

\section{News paper articles and documentaries}

Channel 4. (1999). Brussels Behind Closed Doors. Retrieved from: https://www.youtube.com/watch ?v=pdfr_N2ZkZo. Last accessed December 31, 2019.

Der Spiegel. (27.09.2007). Umweltpolitiker fordern Kommunen zum Handeln auf.

ENDS Europe. (05.12.2005). Council cool on air quality programme.

ENDS Europe. (28.06.2006). Ministers agree new EU air quality limits.

Financial Times. (30.05.1993). No breath of fresh air.

The Guardian. (06.05.1993). Car exhausts blamed for rise in urban hay fever.

The Guardian. (30.05.1993). Hay fever, coughs and sneezes.

The Guardian. (01.06.1993). Coughs and sneezes. 
The Guardian (London). (05.07.1994). Dangerous ozone levels could be a regular feature of hot summer days.

The Guardian (London). (13.07.1994). Labour Attacks health pollution.

The Guardian (London). (18.07.1994). Commentary: Wanted: a politician who will finally clear the air.

The Independent. (16.07.1994). The day Britain choked; UK suffers world's biggest asthma outbreak.

\section{Websites}

CAFE. http://ec.europa.eu/environment/archives/cafe/general/keydocs.htm. Last accessed May 8, 2017.

EP. .http://www.europarl.europa.eu/sides/getDoc.do?type=CRE\&reference=20060926\&secondRef=ITEM008\&language=EN\&ring=A6-2006-0234\#-117. Last accessed: December 29, 2018.

Euractiv A. http://www.euractiv.com/climate-environment/Parliament-softens-eu-clean-air-law/artic le-158251. Last accessed: February 7, 2018.

Euractiv B. https://www.euractiv.com/section/agriculture-food/news/eu-parliament-calls-for-ban-on-elect ric-pulse-fishing/. Last accessed: February 7, 2018.

Publisher's Note Springer Nature remains neutral with regard to jurisdictional claims in published maps and institutional affiliations. 